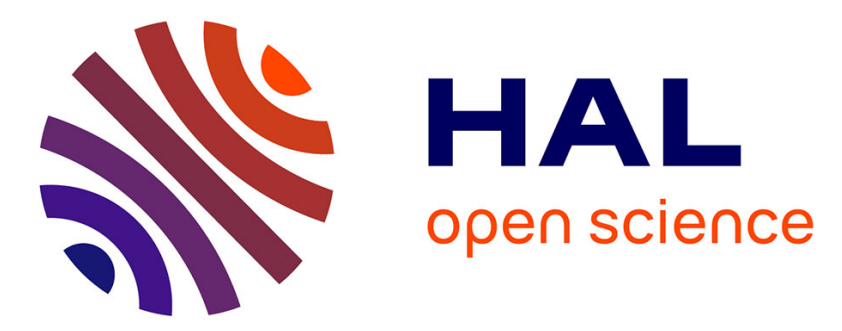

\title{
Chemical oxidation decreases proteolytic susceptibility of skeletal muscle myofibrillar proteins
}

Martine Morzel, Philippe Gatellier, Thierry Sayd, Michel Renerre, Elisabeth Laville

\section{- To cite this version: \\ Martine Morzel, Philippe Gatellier, Thierry Sayd, Michel Renerre, Elisabeth Laville. Chemical oxida- tion decreases proteolytic susceptibility of skeletal muscle myofibrillar proteins. Meat Science, 2006, 73 (3), pp.536-543. 10.1016/j.meatsci.2006.02.005 . hal-02884675}

\section{HAL Id: hal-02884675 \\ https://hal.inrae.fr/hal-02884675}

Submitted on 30 Jun 2020

HAL is a multi-disciplinary open access archive for the deposit and dissemination of scientific research documents, whether they are published or not. The documents may come from teaching and research institutions in France or abroad, or from public or private research centers.
L'archive ouverte pluridisciplinaire HAL, est destinée au dépôt et à la diffusion de documents scientifiques de niveau recherche, publiés ou non, émanant des établissements d'enseignement et de recherche français ou étrangers, des laboratoires publics ou privés.

\section{(ㅇ)(1) $\$$}

Distributed under a Creative Commons Attribution - NonCommercial - NoDerivatives 44.0 


\title{
Chemical oxidation decreases proteolytic susceptibility of skeletal muscle myofibrillar proteins
}

\author{
Martine Morzel, Philippe Gatellier *, Thierry Sayd, Michel Renerre, Elisabeth Laville \\ Qualité des Produits Animaux, INRA, Centre de Theix, 63122 St Genès Champanelle, France
}

Received 28 November 2005; received in revised form 8 February 2006; accepted 8 February 2006

\begin{abstract}
The objective of this study was to investigate the effect of chemical oxidation on proteolysis susceptibility of myofibrillar proteins. Myofibrils were prepared from pig M. longissimus dorsi and oxidised by a hydroxyl radical generating system. Protein oxidation level was measured by the carbonyl content, free thiol group content and bityrosine formation. Oxidised or non-oxidised myofibrillar proteins were exposed to papain and proteolysis was estimated by fluorescence using fluorescamine. Oxidation of myofibrillar proteins was dependent upon the oxidising agent concentration. Disulfide bridge and bityrosine formation indicated that oxidation by $\mathrm{OH}^{\circ}$ can induce protein polymerization. Electrophoretic study showed that myosin was the protein most sensitive to oxidation. Results showed a direct and quantitative relationship between protein damages by hydroxyl radical and decreased proteolytic susceptibility. Electrophoretic observations suggest that polymerization and aggregation may explain in part decreased susceptibility of myofibrillar proteins to proteolysis. (C) 2006 Elsevier Ltd. All rights reserved.
\end{abstract}

Keywords: Myofibrils; Protein oxidation; Carbonyl; Free thiol; Bityrosine; Electrophoresis; Proteolysis

\section{Introduction}

Among eating qualities of meat, texture is rated as most important by the consumer and inconsistent tenderness is a major quality problem in the meat industry. Tenderisation of meat is dependent on several factors, including hydrolysis of structural proteins by endogenous proteolytic enzymes. Proteolysis in meat and meat products is mainly effected by cathepsins (Molly et al., 1997; Roncalés et al., 1995) and calpains (Goll, Thompson, Li, Wei, \& Cong, 2003; Koohmaraie, 1992) but also by proteasome (Taylor et al., 1995).

Postmortem changes in muscle also include a decrease of the antioxidant defense system (Renerre, Dumont, \& Gatellier, 1996; Renerre, Poncet, Mercier, Gatellier, \& Metro, 1999) and an increase in the degree of lipid and pro-

\footnotetext{
${ }^{*}$ Corresponding author. Tel.: +33 4736241 98; fax: +33 473624268 . E-mail address: pgatel@clermont.inra.fr (P. Gatellier).
}

tein oxidation (Martinaud et al., 1997; Mercier, Gatellier, Viau, Remignon, \& Renerre, 1998; Renerre et al., 1999) under the action of free radicals. Formation of carbonyl groups, thiol oxidation and aromatic hydroxylation are the main known chemical modifications of amino acids during oxidation (Davies, 1987; Davies, Delsignore, \& Lin, 1987; Stadtman, 1990, 1993). Oxidation may alter the secondary and tertiary structure of proteins, thereby increasing surface hydrophobicity (Grune, Jung, Merker, \& Davies, 2004; Pacifi, Kono, \& Davies, 1993). It can also lead to aggregate formation through cross links formed between cysteines (disulfide bond) or tyrosines (bityrosine bonds). In oxidative conditions interaction of proteins with other biomolecules can also lead to cross-linking/polymerization. Thus, carbohydrates or aldehydic lipid oxidation products (malondialdehyde or 4-hydroxynonenal) can react with amino groups of proteins to form fluorescent aggregates termed lipofuscin or ceroid (Friguet, Stadtman, \& Szewda, 1994; Grune et al., 2004; Grune, Reinheckel, \& Davies, 1997). Finally, severe oxidation can induce frag- 
mentation through direct attack of peptide bonds by free radicals (Davies, 1987; Stadtman, 1990, 1993).

The interaction between proteolysis and oxidation of proteins has for years been extensively studied in biomedical sciences. Contrasting effects of oxidation on proteolysis (enhancement or impairment) have been reported depending on the type of chemical modification. For example, increase of surface hydrophobicity can enhance protein degradation by proteases (Cervera \& Levine, 1988; Davies, 2001; Davies \& Goldberg, 1987; Levine, Mosoni, Berlett, \& Stadtman, 1996). On the contrary, intermolecular crosslinks and formation of aggregates in highly oxidative conditions can make proteins less susceptible to enzymatic proteolysis. Formation of lipofuscins has also been described to inhibit proteases (Friguet et al., 1994; Grune et al., 2004; Sitte et al., 2000). In eucaryotic cells, the proteasome system has been shown to recognize and degrade mildly oxidized proteins thus minimizing their toxicity, but more severe oxidative stress causes dramatic oxidation of proteins which become resistant to the proteasome system (Davies, 2001).

In meat, the link between enzymatic proteolysis and oxidative processes is rather poorly documented. However, Rowe, Maddock, Lonergan, and Huff-Lonergan (2004a, $2004 \mathrm{~b}$ ) have demonstrated that oxidation of muscle proteins has a negative effect on beef tenderness and attributed this effect to inactivation of $\mu$-calpain and subsequent decrease in proteolysis. The present study was designed to explore the effects of oxidative conditions on proteolysis of myofibrillar proteins from pork muscle. Myofibrils were exposed to different concentrations of hydroxyl radical $\left(\mathrm{OH}^{*}\right)$ generating system and subsequently hydrolysed by papain. Proteolytic susceptibility of oxidised myofibrillar proteins is presented and discussed in relationship to protein modifications such as carbonyl formation, loss of free SH groups, bityrosine formation, and aggregation.

\section{Materials and methods}

\subsection{Animals and samples}

Three Large White crossed Landrace pigs were slaughtered at 6 months of age. About $800 \mathrm{~g}$ of M. longissimus dorsi was removed immediately after bleeding. Fat was trimmed away and muscle was cut into cubes and frozen at $-80^{\circ} \mathrm{C}$ until use.

\subsection{Isolation of myofibrils}

Myofibrils were prepared according to the method of Ouali and Talmant (1990) with some modifications as outlined by Martinaud et al. (1997). Ten grams of frozen muscle were homogenised with a Waring blender in $100 \mathrm{ml}$ of a solution at $\mathrm{pH} 6.5$ containing $150 \mathrm{mM} \mathrm{NaCl}, 25 \mathrm{mM} \mathrm{KCl}$, $3 \mathrm{mM} \mathrm{MgCl} 2,4 \mathrm{mM}$ EDTA, to which two protease inhibitors (PMSF $1 \mathrm{mM}$ and E64 $1 \mu \mathrm{M}$ ) had been added. The homogenate was ground with Polytron for $30 \mathrm{~s}$, and colla- gen was eliminated by filtration on gauze. After $30 \mathrm{~min}$ of stirring in ice, the extract was centrifuged at $2000 \mathrm{~g}$ for $15 \mathrm{~min}$ at $4{ }^{\circ} \mathrm{C}$. The pellet was washed twice with $100 \mathrm{ml}$ of a $50 \mathrm{mM} \mathrm{KCl}$ solution at $\mathrm{pH} 6.4$ and once with $100 \mathrm{ml}$ of $20 \mathrm{mM}$ phosphate buffer at $\mathrm{pH} 6$. The pellet was finally resuspended in the same phosphate buffer, and the protein concentration was adjusted to $14 \mathrm{mg} / \mathrm{ml}$ by the Biuret method (Gornall, Bardawill, \& David, 1949). Two myofibril preparations were performed on three different pigs $(n=6)$.

\subsection{Chemical induction of myofibrils oxidation}

Myofibrils $(10 \mathrm{mg} / \mathrm{ml}$ final concentration) were incubated for $3 \mathrm{~h}$ at $37^{\circ} \mathrm{C}$ in $20 \mathrm{mM}$ phosphate buffer at $\mathrm{pH}$ 6 with $\mathrm{FeSO}_{4} /$ diethylenetriaminepentaacetic acid (DETAPAC) $/ \mathrm{H}_{2} \mathrm{O}_{2}$ (Fenton's reagent) at various concentrations (from 0 to $20 \mathrm{mM}$ ). $\mathrm{H}_{2} \mathrm{O}_{2}$ concentration was adjusted by absorbance at $240 \mathrm{~nm}$. Phosphate was used in this study because, contrarily to other buffers commonly used for protein studies, it has no marked effects on protein oxidation (Davies et al., 1987). After $3 \mathrm{~h}$ no residual $\mathrm{H}_{2} \mathrm{O}_{2}$ could be detected by absorbance at $240 \mathrm{~nm}\left(\varepsilon=43.6 \mathrm{M}^{-1} \mathrm{~cm}^{-1}\right)$ but to prevent subsequent oxidation, butylated hydroxy toluene (BHT $1 \mathrm{mM}$ final concentration) was added to the incubation medium. For thiol groups, bityrosine and proteolysis measurements, oxidising agent must be removed. For this reason, samples were centrifuged at $4000 \mathrm{~g}$ for $10 \mathrm{~min}$ and pellets were washed with $5 \mathrm{ml}$ of $20 \mathrm{mM}$ phosphate buffer at $\mathrm{pH} 6$ and centrifuged $(4000 \mathrm{~g} /$ $10 \mathrm{~min})$.

\subsection{Determination of carbonyl content}

Carbonyl groups were estimated using the method of Oliver, Alin, Moerman, Goldstein, and Stadtman (1987) with slight modifications. Carbonyl groups were detected by reactivity with 2,4-dinitrophenylhydrazine (DNPH) to form protein hydrazones. Two aliquots of $400 \mu \mathrm{l}$ of myofibrillar suspension were centrifuged at $4000 \mathrm{~g}$ for $10 \mathrm{~min}$. One pellet was treated with $1 \mathrm{ml}$ of $2 \mathrm{~N} \mathrm{HCl}$ and the other with an equal volume of $0.2 \%(\mathrm{w} / \mathrm{v}) \mathrm{DNPH}$ in $2 \mathrm{~N} \mathrm{HCl}$. Both samples were incubated for $1 \mathrm{~h}$ at room temperature under agitation. The samples were centrifuged at $4000 \mathrm{~g}$ for $10 \mathrm{~min}$. The pellets were then washed three times with $1 \mathrm{ml}$ of ethanol:ethyl acetate (1:1) to eliminate free DNPH. Myofibrillar proteins were then dissolved in $2 \mathrm{ml}$ of $6 \mathrm{M}$ guanidine $\mathrm{HCl}$ with $20 \mathrm{mM}$ sodium phosphate buffer at $\mathrm{pH}$ 6.5. To remove insoluble material, samples were centrifuged $10 \mathrm{~min}$ at $4000 \mathrm{~g}$. Protein concentration in the supernatant was calculated at $280 \mathrm{~nm}$ in the $\mathrm{HCl}$ control using BSA in $6 \mathrm{M}$ guanidine as standard. Carbonyl concentration was measured on the treated sample by measuring DNPH incorporated on the basis of an absorption of $21.0 \mathrm{mM}^{-1} \mathrm{~cm}^{-1}$ at $370 \mathrm{~nm}$ for protein hydrazones. The results were expressed as nanomoles of DNPH fixed per milligram of protein. 


\subsection{Determination of free thiol $(\mathrm{SH})$ content}

Thiol oxidation was measured by a modification of Ellman's method using 2,2'-dithiobis(5-nitropyridine) DTNP (Winterbourn, 1990). Washed pellets (containing $4 \mathrm{mg}$ of myofibrillar proteins) were dissolved in $3 \mathrm{ml}$ of $100 \mathrm{mM}$ phosphate buffer at $\mathrm{pH} 8$ containing $8 \mathrm{M}$ urea. About $30 \mu \mathrm{l}$ of $10 \mathrm{mM}$ DTNP (stock solution in ethanol) was added and, after an incubation for $1 \mathrm{~h}$ at room temperature, the absorbance at $386 \mathrm{~nm}$ was measured against a blank of protein at the same concentration without DTNP. The absorbance of diluted DTNP was subtracted, and thiol concentration was calculated using an absorption coefficient of $14 \mathrm{mM}^{-1} \mathrm{~cm}^{-1}$. The results were expressed as nanomoles of free thiol per milligram of protein.

\subsection{Determination of bityrosine formation}

Bityrosine formation was estimated by the method of Davies et al. (1987). Washed pellets (containing $10 \mathrm{mg}$ of myofibrillar protein) were dissolved in $3 \mathrm{ml}$ of high ionic buffer $(20 \mathrm{mM}$ phosphate buffer at $\mathrm{pH} 6$ containing $0.6 \mathrm{M} \mathrm{KCl}$ ). Solutions were filtered through filter paper to eliminate residual lipids and insoluble material. Soluble protein concentration was estimated by the Biuret method. Bityrosine content was estimated by fluorescent measurement at $420 \mathrm{~nm}$ (band width $=10 \mathrm{~nm}$ ) after excitation at $325 \mathrm{~nm}$ (band width $=10 \mathrm{~nm}$ ), using a Shimadzu RF1501 spectrofluorophotometer fitted with a $150 \mathrm{~W}$ Xenon lamp. Corrected fluorescence was obtained by dividing measured fluorescence by protein concentration. The results were expressed in arbitrary units.

\subsection{SDS-PAGE gel electrophoresis}

Myofibrils were incubated for $10 \mathrm{~min}$ at $90{ }^{\circ} \mathrm{C}$ in a buffer containing 30\% (v:v) glycerol, $5 \%(\mathrm{v} / \mathrm{v})$ mercaptoethanol, 2.3\% (w/v) SDS, $62.5 \mathrm{mM}$ Tris- $\mathrm{HCl}(\mathrm{pH} 6.8)$ and $0.05 \%(\mathrm{w} / \mathrm{v})$ bromophenol blue. SDS-PAGE was performed according to the method of Laemmli (1970) using $12 \%(17 \times 17 \mathrm{~cm}, 0.8 \mathrm{~mm}$ thick $)$ polyacrylamide gels. The protein load was adjusted to $20 \mu \mathrm{g}$ per lane. Gels were stained with Coomassie blue. Myosin heavy chain and actin band intensities were measured by Quantity one (Biorad).

\subsection{Measurement of proteolysis rates}

Washed pellets (containing $10 \mathrm{mg}$ of myofibrillar proteins) were suspended in $1 \mathrm{ml}$ of $20 \mathrm{mM}$ phosphate buffer at $\mathrm{pH}$ 6. $0.1 \mathrm{mg}(100 \mathrm{U})$ of lyophilised papain (Sigma) was added and suspensions were incubated at $25^{\circ} \mathrm{C}$ under agitation. Papain digestion was terminated by addition at various times $(0,5,10,15,20,25,30,40,60 \mathrm{~min})$ of $10 \%$ (final concentration) trichloroacetic acid (TCA). In prac- tice, $100 \mu \mathrm{l}$ aliquots of reaction mixture were removed and diluted with $400 \mu \mathrm{l}$ of $12.5 \%$ TCA. After centrifugation for $10 \mathrm{~min}$ at $4000 \mathrm{~g}$, the concentration of peptides and aminoacids in the supernatant was measured as described by Friguet et al. (1994) with modifications. Supernatant was first neutralised with $500 \mu \mathrm{l}$ of $2 \mathrm{M}$ potassium borate, $\mathrm{pH} 10.300 \mu \mathrm{l}$ of fluorescamine (Sigma) at a concentration of $0.3 \mathrm{mg} / \mathrm{ml}$ in acetone were added. Reactive volume was finally adjusted to $3 \mathrm{ml}$ with distilled water. Fluorescamine reacts quantitatively with primary amines, forming a fluorescent product which was quantified by fluorescence measurement (excitation at $375 \mathrm{~nm}$; band width $=10 \mathrm{~nm}$ and emission at $475 \mathrm{~nm}$; band width $=10 \mathrm{~nm}$ ). Glycine was used in parallel as amino acid standard. The concentration of primary amines in TCA-soluble fractions reflects the rate of myofibrillar protein proteolysis by papain, expressed in nanomoles of free amino groups per minute per milligram of papain.

\section{Results and discussion}

\subsection{Carbonyl content}

Amino acids with $\mathrm{NH}$ or $\mathrm{NH}_{2}$ groups on their side chains are very reactive to $\mathrm{OH}^{*}$. These groups are transformed to carbonyl groups during protein oxidation (Stadtman, 1990, 1993). In our experiment, carbonyl content in fresh myofibrils (control) was $1.7 \mathrm{nmol} / \mathrm{mg}$ protein (Fig. 1), a value close to those reported by Martinaud et al. (1997) on bovine myofibrils and Liu and Xiong (2000a) on chicken myosin. Incubation for $3 \mathrm{~h}$ at $37^{\circ} \mathrm{C}$ without oxidising agent induced a slight increase $(+12 \%)$ of carbonyl content when compared with fresh myofibrils. Addition of oxidising agent produced an increase in carbonyl content in a concentration dependent manner: between 0 and $3 \mathrm{mM}$, carbonyl content increased linearly following the equation: [carbonyls] $=8.46$ [Fenton's reagent] $+1.14\left(R^{2}=0.991\right)$. From 3 to $10 \mathrm{mM}$, carbonyls further increased to a maximum of $34 \mathrm{nmol} / \mathrm{mg}$ protein, but more slowly, and a lower value was observed at $20 \mathrm{mM}$. Values obtained are fairly consistent with previous experiments on beef myofibrils (Martinaud et al., 1997), while a lower value of $9 \mathrm{nmol} / \mathrm{mg}$ protein was observed by Liu and Xiong (2000a) on purified myosin treated for $1 \mathrm{~h}$ with ferric iron $/ \mathrm{H}_{2} \mathrm{O}_{2}$ /ascorbate, suggesting that the oxidative system used has an influence on oxidation levels. Protein carbonyl content increases during meat ageing but generally remains below levels obtained after chemical oxidation. Antioxidant protection of muscle remaining active for a few days after animal death (Renerre et al., 1999) certainly contributes to limit carbonyl formation. For example, after 10 days of meat ageing, Martinaud et al. (1997) measured carbonyl values of $5.1 \mathrm{nmol} / \mathrm{mg}$ and $6.9 \mathrm{nmol} /$ $\mathrm{mg}$ protein in myofibrils from $M$. longissimus lumborum and $M$. diaphragma pedialis, respectively. In our experiment, such levels were reached at approximately 0.5 $1 \mathrm{mM}$ oxidising agent. 


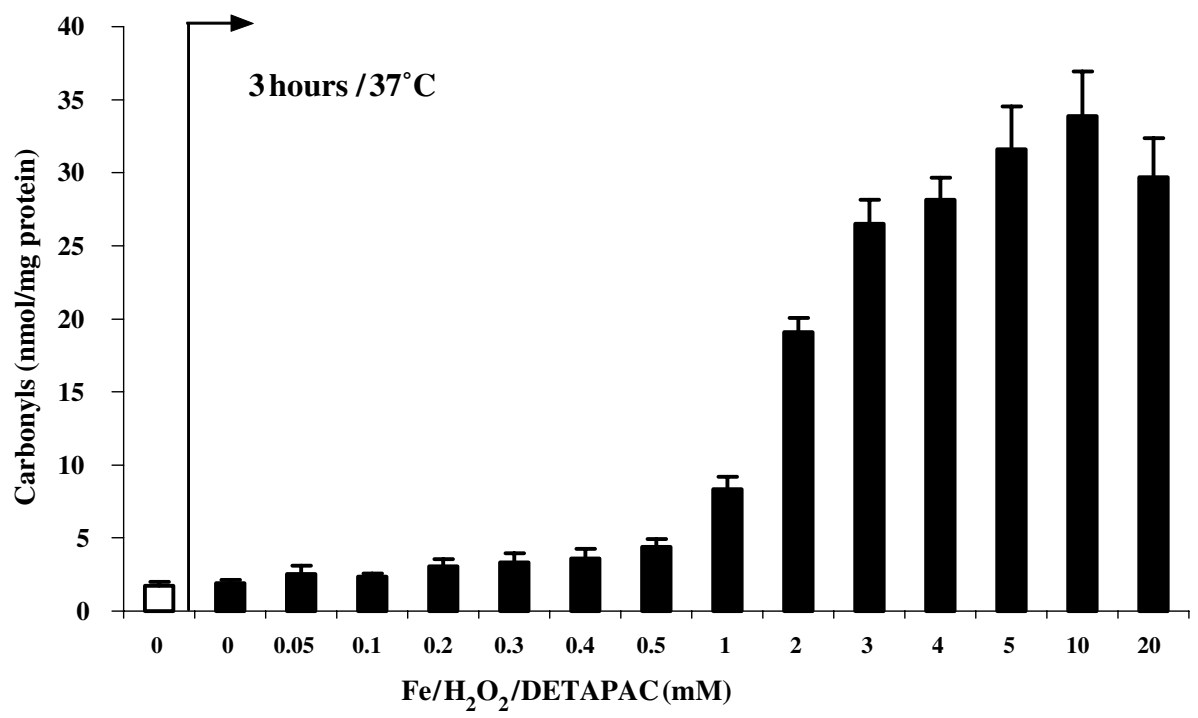

Fig. 1. Effect of different concentrations of free radical generating system on carbonyl content of myofibrillar proteins. White bar corresponds to fresh myofibrils. Values are means \pm SEM of six independent determinations.

\subsection{Free thiol content}

The free thiol content of fresh myofibrils was $33 \mathrm{nmol} /$ mg protein (Fig. 2); i.e. twofold lower than those measured on bovine muscle myofibrils (Martinaud et al., 1997) and rat heart myofibrils (Suzuki, Kaneko, Chapman, \& Dhalla, 1991). Incubation for $3 \mathrm{~h}$ at $37^{\circ} \mathrm{C}$ without oxidising agent induced only a slight decrease $(-4 \%)$ of free thiol content when compared with fresh myofibrils. The level of free thiols was not significantly altered from 0 to $0.2 \mathrm{mM}$ oxidising agent but $80 \%$ of free $\mathrm{SH}$ groups were lost from 0.2 to $20 \mathrm{mM}$ oxidising agent. With exposure of rat myofibrils to xanthine/xanthine oxidase, which is known to generate superoxide radicals, Suzuki et al. (1991) measured a $20 \%$ decrease in $\mathrm{SH}$ content but incubating conditions were milder $\left(30 \mathrm{~min}\right.$ at $\left.30^{\circ} \mathrm{C}\right)$. Contrary to Liu and Xiong
(1996) who indicated that loss of thiol groups in chicken meat could occur without formation of carbonyl derivatives, our results clearly show a correlation between the two phenomena (Table 1) translating the broad spectrum of targets of $\mathrm{OH}^{*}$.

SH loss observed during meat ageing, for example 10 $17 \%$ after 10 days storage, (Martinaud et al., 1997) corresponded in our experiment to $0.3-0.4 \mathrm{mM}$ oxidising agent.

\subsection{Bityrosine formation}

Bityrosine production has been described to be a useful marker for protein modification by $\mathrm{OH}^{*}$ (Davies et al., 1987). An increase in bityrosine has also been evidenced after exposure of myosin to $\mathrm{H}_{2} \mathrm{O}_{2}$-activated metmyoglobin (Hanan \& Shaklai, 1995; Kristensen et al., 1997). In our

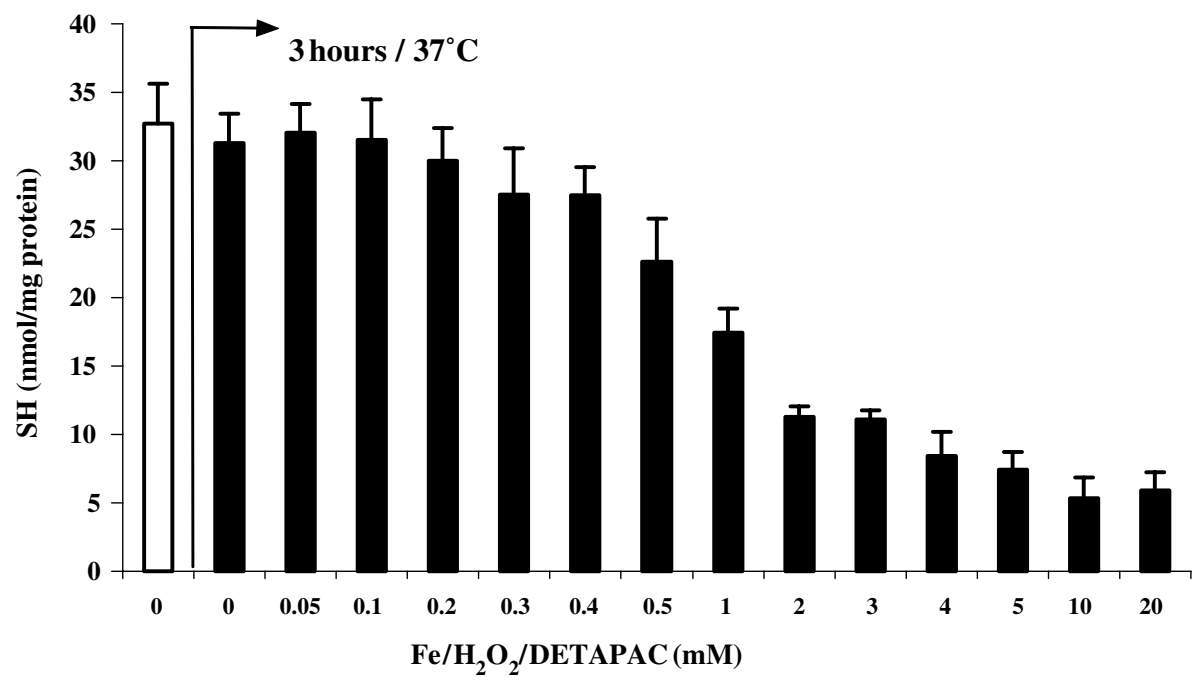

Fig. 2. Effect of different concentrations of free radical generating system on free thiol content of myofibrillar proteins. White bar corresponds to fresh myofibrils. Values are means \pm SEM of six independent determinations. 
Table 1

Correlation matrix between oxidation parameters (carbonyl, free SH and bityrosine), electrophoretic band intensities (myosin HC and actin) and proteolysis rate

\begin{tabular}{lccccc}
\hline & Carbonyl & Free SH & Bityrosine & Myosin HC & Actin \\
\hline Carbonyl & 1 & & & & \\
Free SH & -0.959 & 1 & & & \\
Bityrosine & 0.935 & -0.904 & 1 & 1 & \\
Myosin HC & -0.868 & 0.934 & -0.834 & 0.860 & 1 \\
Actin & -0.837 & 0.845 & -0.836 & 0.919 & 0.871 \\
Proteolysis & -0.942 & 0.979 & -0.930 & 1 \\
\hline
\end{tabular}

Fresh myofibrils were excluded from correlation measurements. All correlations are highly significant $(p<0.01)$.

experiment (Fig. 3), we observed an important and sudden increase of bityrosine formation when myofibrils were exposed to $1 \mathrm{mM}$ oxidising agent. Table 1 shows good correlations between bityrosine formation and other oxidation parameters.

\subsection{Electrophoretic studies}

Electrophoresis was performed in order to observe modifications induced by chemical oxidation of myofibrillar proteins. For example, carbonyls may react with the free amino groups of non oxidised amino acids to form amide bond (Liu \& Xiong, 2000a). If this reaction occurs between different proteins, it can lead to protein polymerisation and aggregate formation. Similarly, thiol oxidation leading to disulfide bonds may generate intermolecular cross-links. Thus, during metal-catalysed oxidation of turkey myofibrillar proteins, Decker, Xiong, Calvert, Crum, and Blanchard (1993) observed high molecular weight polymers, produced by disulfide linkages and mainly derived from myosin and actin. It should be noted, however, that electrophoresis in denaturing conditions breaks up disulfide bonds and aggregates formed through this mechanism can not be visualized. Finally, bityrosine formation between protein molecules can also lead to polymerisation and aggregation (Davies, 1987). Such intermolecular bonding has been observed in oxidised myosin (Hanan \& Shaklai, 1995; Kristensen et al., 1997).

SDS-PAGE patterns showed the decrease of bands corresponding to myosin heavy and light chains after exposure to oxidising agent (Fig. 4). This decrease was especially pronounced between 0.5 and $1 \mathrm{mM}$ oxidising agent, which coincides well with the sharp increase in bityrosine formation. In highly oxidative conditions, high molecular weight compounds, probably aggregates, accumulated at the top of the gel. We therefore propose that polymerisation of myosin intervened mainly via bityrosine formation, in accordance with Kristensen et al. (1997), although aggregation indirectly due to carbonyl formation is also possibly involved. The actin band was relatively more stable and was affected only at higher oxidant concentrations (3 mM), oppositely to Dalle-Donne et al. (2001) who demonstrated that purified actin is particularly prone to chemical oxidation by hypochlorous acid. The difference between these findings are probably explained by accessibility of oxidation sites: in purified actin, such sites are free while in myofibrillar suspensions, interaction of actin with myosin chains may mask oxidation sites.

No fragmentation of myofibrils has been detected in our experiment even in the higher oxidative conditions. This

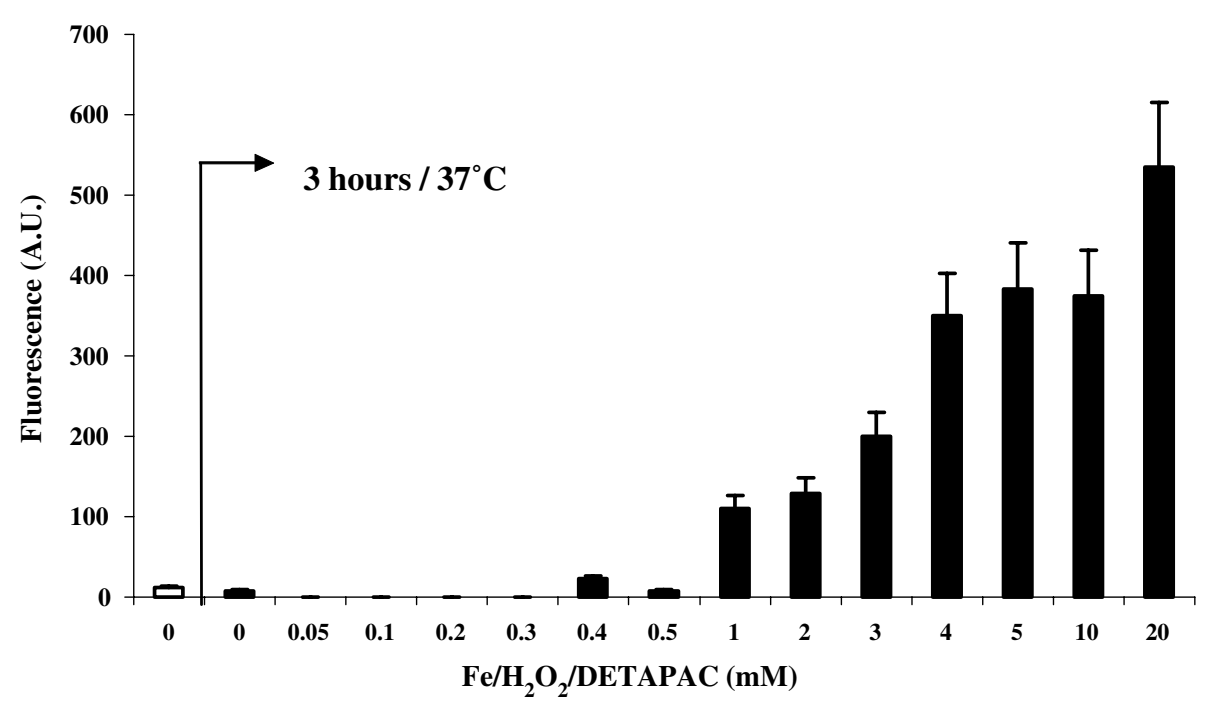

Fig. 3. Effect of different concentrations of free radical generating system on bityrosine formation in myofibrillar proteins measured by fluorescence. White bar corresponds to fresh myofibrils. Values are means \pm SEM of six independent determinations. 


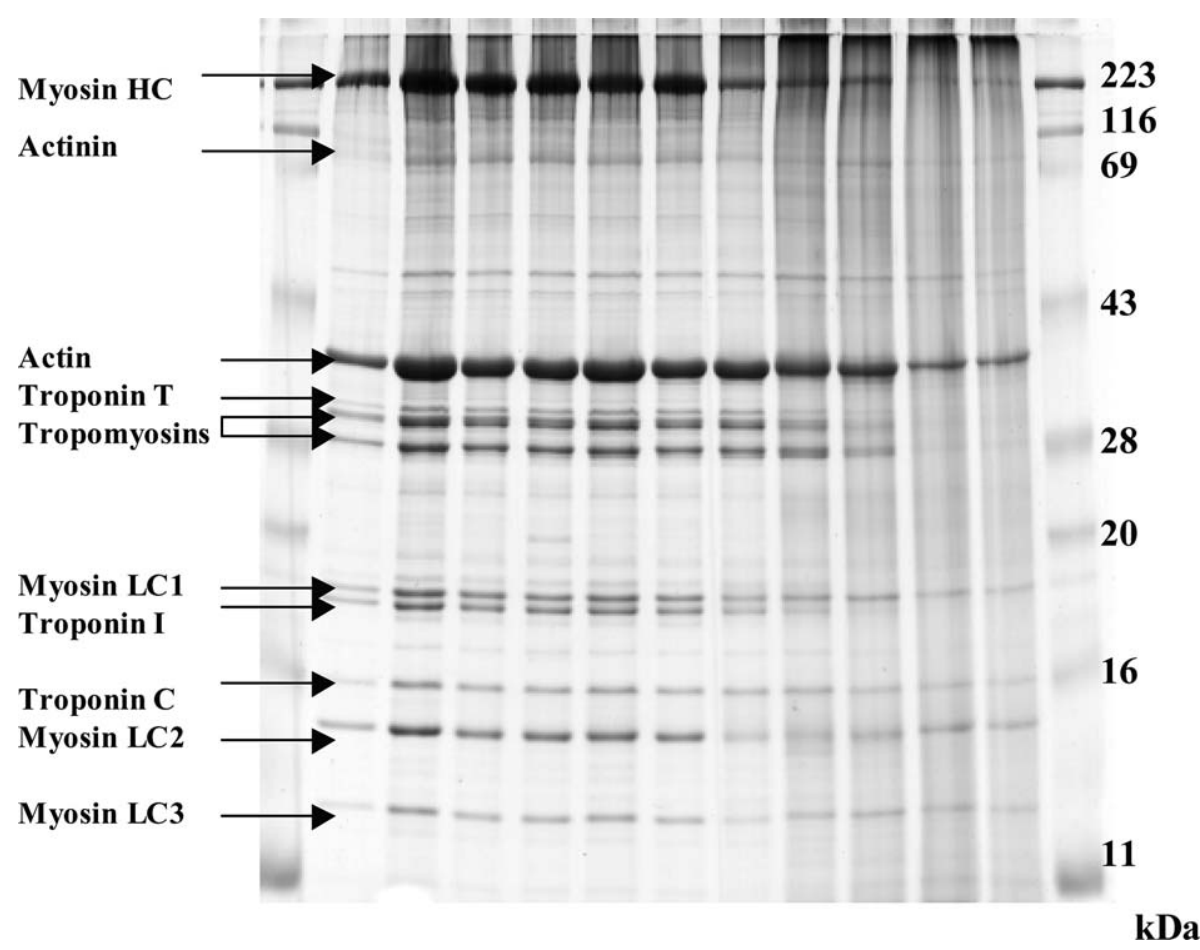

Fig. 4. Gel electrophoresis patterns of myofibrillar proteins oxidised by different concentrations of free radical generating system. Different lanes are from the left to the right; molecular weights, fresh myofibril, oxidised myofibrils (with $0,0.05,0.1,0.3,0.5,1,3,5,10,20$ mM Fenton's reagent) and molecular weights.

result was confirmed by fluorescamine amino acids detection (data not shown) showing no proteolysis during oxidation by Fenton's reagent. Ooizumi and Xiong (2004) also failed to observe myosin fragmentation when chicken myofibrils were exposed to ferric iron/ascorbate $/ \mathrm{H}_{2} \mathrm{O}_{2}$ oxidative system even with a concentration up to $5 \mathrm{mM}$ in $\mathrm{H}_{2} \mathrm{O}_{2}$.

\subsection{Effect of oxidation of myofibrils on proteolytic susceptibility to papain}

Papain is a plant cysteine proteinase. It presents a high homology in amino acids sequence with lysosomal cysteine proteinases (cathepsin L, B and H), especially in the catalytic site (Dufour, 1988). Moreover, papain has an optimum of activity at $\mathrm{pH}$ close to the ultimate $\mathrm{pH}$ in meat. Papain was therefore chosen in this study as a relevant model of a muscle proteolytic system.

Fig. 5 shows the effect of prior oxidative treatments of myofibrils on proteolysis rate by papain. Incubation of myofibrils for $3 \mathrm{~h}$ at $37^{\circ} \mathrm{C}$ without oxidising agent already produced a $24 \%$ decline in the rate of proteolysis by papain when compared with fresh myofibrils. Rate of proteolysis remained stable between 0 and $0.3 \mathrm{mM}$ oxidising agent but further declined at higher concentrations. At $20 \mathrm{mM}$ oxidising agent, a residual proteolysis rate of only $2 \%$ (of the initial rate) was measured. Some authors have recently reported a biphasic response when proteolysis was measured on oxidised proteins (Davies, 2001; Grune et al., 2004): proteolytic susceptibility initially increases before declining at higher oxidant concentration, due to the for- mation of protein aggregates changing both chemical and physical recognition sites. This contrasts with our findings but may be explained by the use of insoluble myofibrillar proteins, spontaneously prone to aggregation, while earlier studies were performed on soluble proteins. On the other hand, our results are in good accordance with those obtained by Kristensen et al. (1997) who showed that oxidative modification of myosin produces high molecular weight aggregates and, at the same time, decreases its susceptibility to proteolytic degradation by cathepsin B. Similarly, Liu and Xiong (2000b) showed that, under non reducing conditions, oxidation decreases the susceptibility of myosin to pepsin, trypsin and chymotrypsin.

To establish links between oxidation and proteolysis, the relationships between indicators of protein oxidation and proteolysis rate were assessed by a correlation study. High correlations were obtained between proteolysis rate and free $\mathrm{SH}$ content as between proteolysis rate and bityrosine formation (Table 1). These results suggest that intermolecular cross-links via disulfide bridges and bityrosine, formed during oxidation, are an important cause of the decrease in proteolysis susceptibility. Importance of polymerisation/ aggregation phenomena was confirmed by correlation measurements between decrease in proteolysis rate and decrease in protein band intensities, due to aggregation, as measured by electrophoresis (Table 1). Furthermore, good correlation was also obtained between carbonyl content and proteolysis rate (Table 1), which was expected since papain is a cysteine endopeptidase hydrolysing proteins at bonds involving Arg, Lys, His, Gly and Leu and 


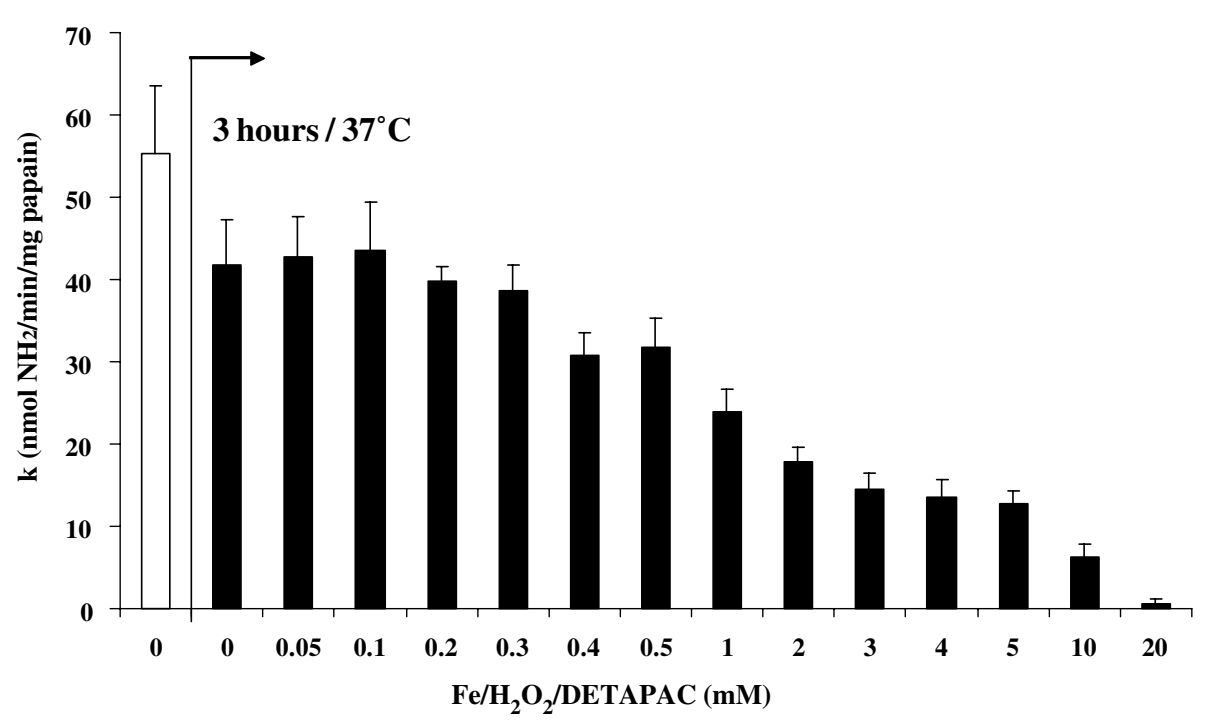

Fig. 5. Effect of prior oxidative treatment by different concentrations of free radical generating system on proteolysis rate $(k)$ of myofibrils by papain. White bar corresponds to fresh myofibrils. Values are means \pm SEM of six independent determinations.

many of these amino acids have their side chains converted to carbonyl groups during oxidation. Our results indicate that oxidation of myofibrillar proteins cause changes, polymerisation (via bityrosine and disulfide bridges) and specific chemical modifications of some amino acids, which can lead directly or indirectly to a decrease in proteolytic susceptibility. Polymerisation with other biomolecules (carbohydrates or lipid oxidation products) has not been studied here but this would be an obvious area to continue to get a further understanding on oxidative modifications in relation to meat quality development.

Even if levels of myofibril oxidation obtained in this model are higher than those produced in situ, this negative effect of oxidation on proteolysis should apply to some extent to meat. This is all the more likely because during meat ageing, proteases are also the target of free radical attacks, especially cysteine proteases that can be oxidized at their active site, which decreases their activity (Rowe et al., 2004b). Therefore, concomitant oxidation of proteases and of their myofibrillar substrates can act in synergy to decrease the extent of muscle tenderisation, especially in conditions generating high levels of lipid and protein oxidation (irradiation, freezing/unfreezing cycles or feeding animals with high unsaturated oils). This was used as an argument by Kristensen et al. (1997) to explain differences between oxidative and glycolytic muscles, the latter being less prone to postmortem lipid and protein oxidation and tenderising faster than oxidative muscle. Similarly, it has been demonstrated recently in beef that high oxygen packaging, a favourable medium for free radical production, has a negative effect on tenderness (Sorheim, Wahlgren, Nilsen, \& Lea, 2004).

Improved antioxidant protection, provided for example by dietary treatment such as vitamin E supplementation (Mercier et al., 1998) and already used to prevent lipid and myoglobin oxidation in meat, could also have a bene- ficial effect on tenderness. This effect needs to be tested before giving recommendations to professionals in the meat industry.

\section{References}

Cervera, J., \& Levine, R. L. (1988). Modulation of the hydrophobicity of glutamine synthetase by mixed function oxidation. FASEB Journal, 2, 2591-2595.

Dalle-Donne, I., Rossi, R., Giustarini, D., Gagliano, N., Lusini, L., Milzani, A., et al. (2001). Actin carbonylation: from a simple marker of protein oxidation to relevant signs of severe functional impairment. Free Radical Biology and Medicine, 31, 1075-1083.

Davies, K. J. A. (1987). Protein damage and degradation by oxygen radicals. I: General aspects. Journal of Biological Chemistry, 262, 9895-9901.

Davies, K. J. A. (2001). Degradation of oxidized proteins by the $20 \mathrm{~S}$ proteasome. Biochimie, 83, 301-310.

Davies, K. J. A., Delsignore, M. E., \& Lin, S. W. (1987). Protein damage and degradation by oxygen radicals. II. Modification of amino acids. Journal of Biological Chemistry, 262, 9902-9907.

Davies, K. J. A., \& Goldberg, A. L. (1987). Proteins damaged by oxygen radicals are rapidly degraded in extracts of red blood cells. Journal of Biological Chemistry, 262, 8227-8234.

Decker, E. A., Xiong, Y. L., Calvert, J. T., Crum, A. D., \& Blanchard, S. P. (1993). Chemical, physical, and functional properties of oxidized turkey white muscle myofibrillar proteins. Journal of Agricultural and Food Chemistry, 41, 186-189.

Dufour, E. (1988). Contribution à la connaissance de la structure d'une cysteine protéinase. Thesis, University Blaise Pascal, Clermont-Ferrand II.

Friguet, B., Stadtman, E. R., \& Szewda, L. I. (1994). Modification of glucose-6-phosphate dehydrogenase by 4-hydroxy-2-nonenal. Formation of cross-linked protein that inhibits the multicatalytic protease. Journal of Biological Chemistry, 269, 21639-21643.

Goll, D. E., Thompson, V. F., Li, H., Wei, W., \& Cong, J. (2003). The calpain system. Physiology Review, 83, 731-801.

Gornall, A. G., Bardawill, C. J., \& David, M. M. (1949). Determination of serum proteins by means of biuret reaction. Journal of Biological Chemistry, 177, 751-766.

Grune, T., Jung, T., Merker, K., \& Davies, K. J. A. (2004). Decreased proteolysis caused by protein aggregates, inclusion bodies, plaques, 
lipofuscin, ceroid, and aggresomes during oxidative stress, aging, and disease. The International Journal of Biochemistry and Cell Biology, 36, 2519-2530.

Grune, T., Reinheckel, T., \& Davies, K. J. A. (1997). Degradation of oxidized proteins in mammalian cells. FASEB Journal, 11, 526-534.

Hanan, T., \& Shaklai, N. (1995). The role of $\mathrm{H}_{2} \mathrm{O}_{2}$-generated myoglobin radical in crosslinking of myosin. Free Radical Research, 22, 215-227.

Koohmaraie, M. (1992). The role of $\mathrm{Ca}^{2+}$-dependent proteases (calpains) in postmortem proteolysis and meat tenderness. Biochimie, 74, 239-245.

Kristensen, L., Moller, A. J., \& Andersen H. J. (1997). Degradation of myosin by cathepsin B. Comparison of native and oxidatively modified protein. In Proceedings of 43rd international congress of meat science and technology (pp. 412-413), July 97, Auckland, New Zealand.

Laemmli, U. K. (1970). Cleavage of structural proteins during the assembly of the head of bacteriophage T4. Nature, 227, 680 .

Levine, R. L., Mosoni, L., Berlett, B. S., \& Stadtman, E. R. (1996). Methionine residues as endogenous antioxidants in proteins. Proceedings of National Academy of Sciences of the USA, 93, 15036-15040.

Liu, G., \& Xiong, Y. L. (1996). Contribution of lipid and protein oxidation to rheological differences between chicken white and red muscle myofibrillar proteins. Journal of Agricultural and Food Chemistry, 44, 779-784.

Liu, G., \& Xiong, Y. L. (2000a). Oxidatively induced chemical changes and interactions of mixed myosin, B-lactoglobulin and soy 7S globulin. Journal of the Science of Food and Agriculture, 80, 1601-1607.

Liu, G., \& Xiong, Y. L. (2000b). Electrophoretic pattern, thermal denaturation, and in vitro digestibility of oxidized myosin. Journal of Agricultural and Food Chemistry, 48, 624-630.

Martinaud, A., Mercier, Y., Marinova, P., Tassy, C., Gatellier, P., \& Renerre, M. (1997). Comparison of oxidative processes on myofibrillar proteins from beef during maturation and by different model oxidation systems. Journal of Agricultural and Food Chemistry, 45, 2481-2487.

Mercier, Y., Gatellier, P., Viau, M., Remignon, H., \& Renerre, M. (1998). Effect of dietary fat and vitamin $\mathrm{E}$ on lipid and protein oxidation in turkey meat during storage. Meat Science, 48, 301-317.

Molly, K., Demeyer, D., Johansson, G., Raemaekers, M., Ghistelinck, M., \& Geenen, I. (1997). The importance of meat enzymes in ripening and flavour generation in dry fermented sausages. First results of a European project. Food Chemistry, 59, 539-545.

Oliver, C. N., Alin, B. W., Moerman, E. J., Goldstein, S., \& Stadtman, E. R. (1987). Age-related changes in oxidized proteins. Journal of Biological Chemistry, 262, 5488-5491.

Ooizumi, T., \& Xiong, Y. L. (2004). Biochemical susceptibility of myosin in chicken myofibrils subjected to hydroxyl radical oxidizing system. Journal of Agricultural and Food Chemistry, 52, 4303-4307.
Ouali, A., \& Talmant, A. (1990). Calpain and Calpastatin distribution in bovine, porcine and ovine skeletal muscles. Meat Science, 28, 331-348.

Pacifi, R. E., Kono, Y., \& Davies, K. J. A. (1993). Hydrophobicity as the signal of selective degradation of hydroxyl radical-modified haemoglobin by the multicatalytic proteinase complex, proteasome. Journal of Biological Chemistry, 268, 15405-15411.

Renerre, M., Dumont, F., \& Gatellier, P. (1996). Antioxidant enzyme activities in beef in relation to oxidation of lipid and myoglobin. Meat Science, 43, 111-121.

Renerre, M., Poncet, K., Mercier, Y., Gatellier, P., \& Metro, B. (1999). Influence of dietary fat and vitamin $\mathrm{E}$ on antioxidant status of muscles of turkey. Journal of Agricultural and Food Chemistry, 47, 237-244.

Roncalés, P., Geesink, G. H., van Laak, R. L. J. M., Jaime, I., Beltraan, J. A., Barnier, V. H. M., et al. (1995). Meat tenderisation: enzymatic mechanisms. In A. Ouali, D. I. Demeyer, \& F. J. M. Smulders (Eds.), Expression of tissue proteinases and regulation of protein degradation as related to meat quality (pp. 331-332). ECCEAMST.

Rowe, L. J., Maddock, K. R., Lonergan, S. M., \& Huff-Lonergan, E. (2004a). Influence of early postmortem protein oxidation on beef quality. Journal of Animal Science, 82, 785-793.

Rowe, L. J., Maddock, K. R., Lonergan, S. M., \& Huff-Lonergan, E. (2004b). Oxidative environments decrease tenderization of beef steaks through inactivation of $\mu$-calpain. Journal of Animal Science, 82, 3254-3266.

Sitte, N., Huber, M., Grune, T., Ladhoff, A., Doecke, W. D., von Zglinicki, T., et al. (2000). Proteasome inhibition by lipofuscin/ceroid during postmitotic aging of fibroblasts. FASEB Journal, 14, 1490-1498.

Sorheim, O., Wahlgren, M., Nilsen, B. N., \& Lea, P. (2004). Effects of high oxygen packaging on tenderness and quality characteristics of beef longissimus muscles. In Proceedings of 50th international congress of meat science and technology (p. 120), Helsinki, Finland.

Stadtman, E. R. (1990). Metal ion-catalysed oxidation of proteins: biochemical mechanism and biological consequences. Free Radical Biology and Medicine, 8, 315-325.

Stadtman, E. R. (1993). Oxidation of free amino acids and amino acids residues in proteins by radiolysis and by metal-catalyzed reactions. Annual Review of biochemistry, 62, 797-821.

Suzuki, S., Kaneko, M., Chapman, D. C., \& Dhalla, N. S. (1991). Alteration in contractile proteins due to oxygen free radicals. Biochimica Biophysica Acta, 1074, 95-100.

Taylor, R. G., Tassy, C., Briand, M., Robert, N., Briand, Y., \& Ouali, A. (1995). Proteolytic activity of proteasome on myofibrillar structures. Molecular Biology and Reproduction, 21, 71-74.

Winterbourn, C. C. (1990). Oxidative reactions of hemoglobin. Methods in Enzymology, 186, 265-272. 